\title{
Interpretive Structural Analysis of Interrelationships of the Sustainable Development Goals (SDGs) in Iran
}

\author{
Kiarash Fartash $^{1 *}$, Mohammadsadegh Khayatian ${ }^{1}$, Amir Ghorbani $^{2}$, Aliasghar Sadabadi $^{1}$ \\ ${ }^{1}$ Institute for Science and Technology Studies, Shahid Beheshti University, Tehran 1983969411, Iran \\ ${ }^{2}$ Faculty of Management and Accounting, Shahid Beheshti University, Tehran 1983969411, Iran
}

Corresponding Author Email: k_fartash@sbu.ac.ir

https://doi.org/10.18280/ijsdp.160116

Received: 19 July 2020

Accepted: 31 December 2020

\section{Keywords:}

sustainable development goal, SDGs, interpretive structural modeling, ISM, MICMAC analysis, Iran

\begin{abstract}
Sustainable Development Goals (SDGs) provide an ambitious agenda to end poverty and its dimensions and a sustainable, prosperous, and fair future. The aim of our paper is to assess the significance of SDGs from the perspective of Iran. To this end, the method of ISM has been used to express the interrelationships between SDGs. Besides, MICMAC method was utilized to assess dependence and driving power of every SDG. By data analyzing, SDGs were classified into six different levels and were modeled according to the interrelationships between them. Variables then were divided into three groups of dependent, independent/driving, communication, and autonomous variables, and no variable was included in the group of linkage variables. The findings show that SDGs12 and SDGs4 are the most fundamental goals of sustainable development, considering the needs, development stages, capacities of Iran. Achieving them is the basis for achieving other goals.
\end{abstract}

\section{INTRODUCTION}

The world has experienced major advances since the advent of $21^{\text {st }}$ century. Extreme poverty has been diminished to half, child mortality is declining and literacy in youth has achieved an unprecedented record. However, despite these achievements, serious challenges persists. More efforts have to be put to alleviate poverty, including all of its forms, and to deliver the Millennium Development Goals (MDGs) unfinished targets. We must go beyond economic indicators of development to encompass all spheres of sustainable development and more generally well-being [1].

In this regard, the long-term goals of global achievement in the 21 st century were presented in a document called "Transforming our world: the 2030 agenda for sustainable development" which provides a pragmatic approach to recon ciliate collective action towards shared goals [2]. The 2030 Agenda entails seventeen goals, called Sustainable Development Goals (SDGs), consist of 169 targets and 232 indicators [3]. This agenda was the key result of the Rio +20 Sustainable Development Summit held in 2012 [4] and approved by the UN General Assembly in September 2015 by UN's 193 member states. The SDGs are a global initiative to wipe out poverty establish an equal, just and secure world for the people of planet Earth. They have been formulated in a consultative process that gathered governments and citizens globally to work together and create an ambitious plan of actions [5]. They are now the main reference for development policies and programs at the national level. Each country reviews 17 goals to determine how they can be turned into practical but ambitious development programs, and how national resources can be mobilized based on needs, stage of development, capacities, resources, and strategies to produce a real change [6]. Besides, consensuses reached in Addis
Ababa, Istanbul [7], as well as Paris on climate change in further strengthen this agenda [8].

The president of Iran in his speech at the UN Summit in 2015 emphasized Iran's active participation in the preparation of the 2030 Agenda and stated that Iran's cooperation will continue to fulfill its commitments. In this regard, in 2015, the 2030 agenda was approved by the Cabinet in the Government of Iran, and various ministries and government organizations were responsible for its implementation. The committee on sustainable development of Iran has the custodian of coordinating and monitoring how to achieve these goals. Since 2015, various government organizations such as the Planning and Budget Organization, Department of Environment, Vice Presidency for Women and Family Affairs, the Ministry of Energy have organized various workshops and meetings with the aim of promoting public awareness on the SDGs in Iran. Besides, the Iranian National UNESCO Commission has organized classes aimed at promoting gender equality and women's empowerment in Iran. Achieving 59th rank out of 166 countries in the global SDGs index in 2020 and 30-step growth compared to 2018 shows the Iranian government's attention to sustainable development. Iran also has the highest rank in this index in the Mena region and in indicators such as affordable \& clean energy, quality of education, and good health \& well-being has grown in recent years [9]. The total installed capacity of renewable power plants in 2019 compared to 2020 , increased by $18 \%$ that reached $820 \mathrm{MW}$. This has led to a 53\% increase in emissions avoidance in 2019 compared to 2020 [10]. As Iran faces challenges and weakness in various indicators such as zero hunger, gender equality, decent work and economic growth, reduced inequalities and peace, justice and strong institutions [9], paying attentions to SDGs would play a key role in tackling with them. In 2019, Iran was ranked 99th in the world in the global 
competitiveness index, which compared to 2018, has weakened its position by 10 levels and was ranked 140th in the world in the labor market index. [11]. We are facing a situation in Iran and the Mena region where the continuation of the old patterns is no longer sustainable and we need to change the prevailing pattern and move towards sustainable development [7].

The 2030 Agenda is a common foundation for addressing the mentioned problems and challenges that threaten the wellbeing and livelihood of humanity now and in the future. The countries of the Mena region and Iran can use SDGs as the guiding basis for their action and policy efforts. However, as of now, the pace of their implementation fluctuates from country to country depending on their domestic preconditions, challenges \& capacities. Although the SDGs provide a promising roadmap for the development of the Mena region and a country like Iran, recent progress of Iran in ending Extreme poverty, promoting clean energy, and facilitating access to energy services in remote villages [9] as well as the growth of health care activities [12], Food Safety and Security, Rural Development, quality education, life below water [9], and knowledge-based Economics [13] show the understanding of the need for sustainable development by Iranian policymakers. However as stated, Iran faces significant challenges and weakness in various indicators such as zero hunger, gender equality, decent work and economic growth, reduced inequalities and peace, justice and strong institutions [9] which highlight the need for a plan to achieve SDGs in this country, Still, as mentioned, the pace of their implementation depends on the specific challenges, preconditions, and capacities of each country [14]. Therefore, the prioritization of SDGs is of great importance in terms of the resources, capabilities, and context of each country to plan to achieve the set goals.

The aim of current paper is to create a hierarchical framework of SDGs using the interpretive structural modeling (ISM) modeling method to provide a tool to help policymakers implement SDGs in Iran. The ISM method has been used by many researchers to create hierarchical models and priority structures in various fields. Recently, the ISM approach has been used by Kumar et al. [4] and Zaini and Akhtar [15] to model SDGs. The application of ISM in each country provides a hierarchy of factors based on local requirements to policymakers and researchers that can be used in current and future planning to achieve sustainable development based on each country's specific priorities and issues. In the rest of the article, in the literature review section, first, the origins of SDGs are discussed and then an overview of researches is presented. In the next section, the research method and steps of interpretive structural modeling (ISM) are discussed. In the fourth section, the findings of the SDGs hierarchical model in Iran and MICMAC analysis are presented. In the next section, we will discuss and compare the findings of the present study with other studies. In the final section, we discuss implications for decision-makers and policymakers.

\section{LITERATURE REVIEW}

In the 18th century, economic theorists such as Adam Smith referred to developmental issues. In the nineteenth century, Karl Marx and classical economists such as Malthus, Ricardo, and Mill also presented material on some elements of sustainable development [16]. Because development policies focused on economic growth in the 18th century led to critical environmental challenges [17], the United Nations convened the 1972 Human Environment Conference in Stockholm and symbolized the conception of the sustainable development (SD) concept. The summit encouraged all countries to reinforce policies regarding environmental management as their economies develops [18] in 1980 with the support of FAO, UNESCO, and the World Wide Fund (WWF) for Nature and the United Nations Environment Program (UNEP) and with the participation of governments, NGOs and experts gathered to publish the World Conservation Strategy Document. This was the first document to acknowledge nature conservation's role in the process of developing resources for human needs [19].

In 1987, the World Commission on the Environment and Development presented a study entitled "Our Common Future". It was the first time that sustainable development was described as a development meeting the requirement of the now without endangering the ability of next descendants to fulfill theirs [20]. In 1992, the Environmental and Development Conference was held in Brazil to address environment and development in a universal scope [18]. In 2000, the United Nations Millennium Summit was held in which 189 countries signed the Millennium Development Goals (MDGs) focusing on poverty eradication [19]. In 2012, the United Nations convened the Rio +20 Summit which identified the green economy as the resolve to disputes of development and environment. Subsequently in 2015 Sustainable Development Summit was convened [21]. In this submit, the first implementation of the MDGs was examined, and "Transforming Our World: Agenda 2030 for Sustainable Development" plan was approved. SDGs have altered the definition of development. In addition to economic growth, UN introduced inclusive growth as well as sustainable development, including environmental, social, and economic aspects [22]. The 2030 Agenda entails seventeen goals, called Sustainable Development Goals (SDGs). The aim of this agenda is building a better future for humanity. In the following, the SDGs and its Implication are stated in Table 1.

Since the 17 SDGs were set by the UN, various studies have been conducted on SDGs, and various researchers have tried to research about SDGs based on their country's background. Zaini and Akhtar [15] used the ISM model to examine the importance of SDGs from an Indian perspective, and after analyzing, they classified SDGs into ten different levels and showed that SDG4 is more important. Also, Kumar et al. [4] also examined the complex interactions among SDGs and the use of the ISM method to help developing and less developed countries to improve their strategic planning to achieve a specific goal over some time. They classified SDGs into twelve levels, which, like Zaini and Akhtar's [15] studies, SDGs 4 is of high importance but differ from each other at other levels. Türkeli [5] investigated performance interdependencies of SDGs scores for 162 UN Member States. The results reflected the key influential drivers are SDG 9, 11 and 12 at a global level. Using the network analysis method, Dalampira and Nastis [23] seek to investigate how SDGs can be simplified as a concept and framework using the Venn diagram of sustainable development. Pongiglione [24] also emphasizes the need to prioritize and categorize SDGs, stating that the main focus should be on goals that achieving them serves as a tool to achieve other goals. Singh [25] also states that SDGs can be considered "destination without a path" because they are a set of integrated but unplanned goals. He 
then tries to use the Strategic Sustainable Development and Transition Management frameworks to identify strategic policy directions and understand SDGs' policy priorities and relationships with each other to help policymakers determine how institutions are structured to manage and regulate activities to achieve SDGs. Allen et al. [26] also state that in order for countries to start implementing SDGs, they need to create a database for decision-making and action. They evaluate SDGs and prioritize them by adopting a MCDM framework and through an investigation of 22 Arab countries. Additionally, Weitz et al. [27] also emphasize the importance of understanding the relationship between SDGs and their prioritization for effective policy-making and planning and use the cross-impact matrix and network analysis to examine the interactions between SDGs and their prioritization.

Table 1. UN SDGs

\begin{tabular}{|c|c|c|}
\hline NO & Goals & Implication \\
\hline 1 & No Poverty & $\begin{array}{c}\text { End poverty in all its forms } \\
\text { everywhere }\end{array}$ \\
\hline 2 & Zero Hunger & $\begin{array}{c}\text { End hunger, achieve food security and } \\
\text { improved nutrition, and promote } \\
\text { sustainable agriculture }\end{array}$ \\
\hline 3 & $\begin{array}{l}\text { Good Health \& } \\
\text { Well-Being }\end{array}$ & $\begin{array}{c}\text { Ensure healthy lives and promote } \\
\text { wellbeing for all at all ages }\end{array}$ \\
\hline 4 & $\begin{array}{l}\text { Quality } \\
\text { Education }\end{array}$ & $\begin{array}{c}\text { Ensure inclusive and equitable quality } \\
\text { education and promote lifelong } \\
\text { learning opportunities for all }\end{array}$ \\
\hline 5 & Gender Equality & $\begin{array}{c}\text { Achieve gender equality and empower } \\
\text { all women and girls }\end{array}$ \\
\hline 6 & $\begin{array}{l}\text { Clean Water \& } \\
\text { Sanitation }\end{array}$ & $\begin{array}{c}\text { Ensure availability and sustainable } \\
\text { management of water and sanitation } \\
\text { for all }\end{array}$ \\
\hline 7 & $\begin{array}{l}\text { Affordable \& } \\
\text { Clean Energy }\end{array}$ & $\begin{array}{l}\text { Ensure access to affordable, reliable, } \\
\text { sustainable and modern energy for all }\end{array}$ \\
\hline 8 & $\begin{array}{l}\text { Decent Work \& } \\
\text { Economic } \\
\text { Growth }\end{array}$ & $\begin{array}{c}\text { Promote sustained, inclusive and } \\
\text { sustainable economic growth, full and } \\
\text { productive employment, and decent } \\
\text { work for all }\end{array}$ \\
\hline 9 & $\begin{array}{c}\text { Industry, } \\
\text { Innovation, \& } \\
\text { Infrastructure }\end{array}$ & $\begin{array}{l}\text { Build resilient infrastructure, promote } \\
\text { inclusive and sustainable } \\
\text { industrialisation, and foster innovation }\end{array}$ \\
\hline 10 & $\begin{array}{c}\text { Reduced } \\
\text { Inequalities }\end{array}$ & $\begin{array}{c}\text { Reduce inequality within and among } \\
\text { countries }\end{array}$ \\
\hline 11 & $\begin{array}{c}\text { Sustainable } \\
\text { Cities \& } \\
\text { Communities }\end{array}$ & $\begin{array}{c}\text { Make cities and human settlements } \\
\text { inclusive, safe, resilient and } \\
\text { sustainable }\end{array}$ \\
\hline 12 & $\begin{array}{l}\text { Responsible } \\
\text { Consumption \& } \\
\text { Production }\end{array}$ & $\begin{array}{l}\text { Ensure sustainable consumption and } \\
\text { production patterns }\end{array}$ \\
\hline 13 & Climate Action & $\begin{array}{l}\text { Take urgent action to combat climate } \\
\text { change and its impacts }\end{array}$ \\
\hline 14 & $\begin{array}{l}\text { Life Below } \\
\text { Water }\end{array}$ & $\begin{array}{c}\text { Conserve and sustainably use the } \\
\text { oceans, seas and marine resources for } \\
\text { sustainable development }\end{array}$ \\
\hline 15 & Life on Land & $\begin{array}{c}\text { Protect, restore and promote } \\
\text { sustainable use of terrestrial } \\
\text { ecosystems, sustainably manage } \\
\text { forests, combat desertification and halt } \\
\text { and reverse land degradation, and halt } \\
\text { biodiversity loss }\end{array}$ \\
\hline 16 & $\begin{array}{l}\text { Peace, Justice \& } \\
\text { Strong } \\
\text { Institutions }\end{array}$ & $\begin{array}{l}\text { Promote peaceful and inclusive } \\
\text { societies for sustainable development, } \\
\text { provide access to justice for all and } \\
\text { build effective, accountable and } \\
\text { inclusive institutions at all levels }\end{array}$ \\
\hline 17 & Partnerships & $\begin{array}{c}\text { Strengthen the means of } \\
\text { implementation and revitalise the }\end{array}$ \\
\hline
\end{tabular}

\begin{tabular}{ccc}
\hline NO & Goals & Implication \\
\hline & global partnership for sustainable \\
& development \\
\hline
\end{tabular}

Source: UN [7]

Table 2. Summary of past works addressing the SDGs

\begin{tabular}{|c|c|}
\hline Researchers & $\begin{array}{c}\text { Findings } \\
\end{array}$ \\
\hline Türkeli [5] & $\begin{array}{c}\text { Investigating multifaceted interdependencies of } \\
\text { all SDGs performance scores. Research } \\
\text { concluded that SDG } 9,11 \text { and } 12 \text { are the key } \\
\text { performance drivers }\end{array}$ \\
\hline Singh [25] & $\begin{array}{l}\text { Singh states that SDGs are a set of integrated } \\
\text { but unplanned goals, she uses the Strategic } \\
\text { Sustainable Development and Transition } \\
\text { Management frameworks to identify strategic } \\
\text { policy directions and understand SDGs' policy } \\
\text { priorities and relationships among SDGs to take } \\
\text { action. }\end{array}$ \\
\hline $\begin{array}{c}\text { Zaini \& } \\
\text { Akhtar [15] }\end{array}$ & $\begin{array}{l}\text { They use the ISM model to examine the } \\
\text { importance of SDGs from an Indian } \\
\text { perspective, and after analyzing, they classify } \\
\text { SDGs into ten different levels and show that } \\
\text { SDG4 is more important. }\end{array}$ \\
\hline $\begin{array}{l}\text { Allen, et al } \\
{[26]}\end{array}$ & $\begin{array}{l}\text { They state that for countries to start } \\
\text { implementing SDGs, they need to create a } \\
\text { database for decision-making and action. They } \\
\text { evaluate SDGs and prioritize them by adopting } \\
\text { a MCDM framework, through a case-study of } \\
22 \text { Arab countries. }\end{array}$ \\
\hline $\begin{array}{c}\text { Dalampira \& } \\
\text { Nastis [23] }\end{array}$ & $\begin{array}{l}\text { Using the network analysis method, they seek to } \\
\text { investigate how SDGs can be simplified as a } \\
\text { concept and framework using the Venn diagram } \\
\text { of sustainable development. }\end{array}$ \\
\hline $\begin{array}{c}\text { Weitz, et al } \\
\text { [27] }\end{array}$ & $\begin{array}{c}\text { By emphasizing the importance of } \\
\text { understanding the relationship among SDGs } \\
\text { and their prioritization for effective policy- } \\
\text { making and planning, and use the cross-impact } \\
\text { matrix and network analysis to examine the } \\
\text { interactions between SDGs and their } \\
\text { prioritization. }\end{array}$ \\
\hline $\begin{array}{c}\text { Kumar, et al } \\
{[4]}\end{array}$ & $\begin{array}{c}\text { They examined the interactions between SDGs } \\
\text { and the use of the ISM method to help } \\
\text { developing and less developed countries to } \\
\text { improve their strategic planning to achieve a } \\
\text { specific goal over a while. They classified } \\
\text { SDGs into twelve levels, in which, like Zaini } \\
\text { and Akhtar's (2019) studies, SDGs } 4 \text { is of high } \\
\text { importance. }\end{array}$ \\
\hline $\begin{array}{c}\text { Pongiglione } \\
{[24]}\end{array}$ & $\begin{array}{l}\text { By emphasizing the need to prioritize and } \\
\text { categorize SDGs, she states that the main focus } \\
\text { should be on goals that achieving them serves } \\
\text { as a tool to achieve other goals. }\end{array}$ \\
\hline
\end{tabular}

Taken together, different studies (Table 2) suggest that countries can use SDGs as guiding principles for policymaking and their measures to achieve sustainable development [1]. Therefore, the prioritization of SDGs is of great importance in terms of the resources, capabilities, and context of each country to plan to achieve the set goals. This paper aims to create a hierarchical model of SDGs using the interpretive structural modeling (ISM) modeling method to provide policymakers with a tool to help them implement SDGs in Iran. Although current paper is methodologically similar to Kumar et al. [4] and Zaini and Akhtar [15], they differ in spatial and temporal domains with this research. This research is conducted in 2019, while the aforementioned studies were done in 2016 and 2017. In addition, this research is dedicated to study spatial territory of Iran, while they 
examined spatial territory of India. Therefore, the difference in terms of context would make a significant difference in the results and their implications. All of this leads to a complete differentiated result.

\section{RESEARCH METHODOLOGY}

Interpretive Structural Modeling was proposed by Warfield (1973) to examine complex socio-economic systems [28]. It is different from conventional approaches in using quantitative variables [29]. ISM is an interactive process of learning with a set of different elements that are structured to shape a holistic meticulous model and explains complex schema of conceptual relationships of a set of variables [30, 31]. This method has a mathematical basis, a philosophical basis, and an analytical and conceptual structure, and provides a tool to transform the mental hierarchy into well-defined patterns for planning. Unlike conventional questionnaires in which respondents just score the importance of issues, ISM requires respondents to assess different linkages among issues [30]. In this method, there is no specific criterion for determining the number of experts [28]. However, according to sources [28, 32], 15 experts have been selected, as shown in Table 3.

Table 3. Profiles of selected experts

\begin{tabular}{|c|c|c|c|}
\hline NO & Organization & Position & $\begin{array}{c}\text { Experience in } \\
\text { years }\end{array}$ \\
\hline 1 & University (Academia) & $\begin{array}{l}\text { Associate } \\
\text { professor }\end{array}$ & 25 \\
\hline 2 & Ministry of Energy & $\begin{array}{l}\text { General } \\
\text { manager }\end{array}$ & 23 \\
\hline 3 & $\begin{array}{l}\text { Ministry of Industry, } \\
\text { Mine \& Trade }\end{array}$ & $\begin{array}{c}\text { Senior civil } \\
\text { servant }\end{array}$ & 22 \\
\hline 4 & Ministry of Education & $\begin{array}{c}\text { Senior civil } \\
\text { servant }\end{array}$ & 20 \\
\hline 5 & State-owned Enterprise & $\begin{array}{c}\text { Department } \\
\text { head }\end{array}$ & 19 \\
\hline 6 & Ministry of Agriculture & $\begin{array}{c}\text { Senior civil } \\
\text { servant }\end{array}$ & 19 \\
\hline 7 & $\begin{array}{c}\text { Planning and Budget } \\
\text { Organization }\end{array}$ & $\begin{array}{c}\text { General } \\
\text { manager }\end{array}$ & 18 \\
\hline 8 & Private Company & $\begin{array}{l}\text { Board of } \\
\text { directors }\end{array}$ & 16 \\
\hline 9 & $\begin{array}{c}\text { Iran National } \\
\text { Innovation Fund }\end{array}$ & $\begin{array}{c}\text { Senior civil } \\
\text { servant }\end{array}$ & 16 \\
\hline 10 & $\begin{array}{c}\text { Department of } \\
\text { Environment }\end{array}$ & $\begin{array}{c}\text { Senior } \\
\text { researcher }\end{array}$ & 15 \\
\hline 11 & University (Academia) & $\begin{array}{l}\text { Assistant } \\
\text { Professor }\end{array}$ & 13 \\
\hline 12 & $\begin{array}{l}\text { Ministry of Economic } \\
\text { Affairs \& Finance }\end{array}$ & Senior expert & 12 \\
\hline 13 & $\begin{array}{c}\text { Vice Presidency for } \\
\text { Science \& Technology }\end{array}$ & $\begin{array}{c}\text { Senior civil } \\
\text { servant }\end{array}$ & 10 \\
\hline 14 & $\begin{array}{c}\text { Parliament Research } \\
\text { Centre }\end{array}$ & Researcher & 9 \\
\hline 15 & University (Academia) & $\begin{array}{l}\text { Assistant } \\
\text { Professor }\end{array}$ & 9 \\
\hline
\end{tabular}

To collect data from primary and secondary data, which have been used appropriately, first, the researchers reviewed the secondary sources (policy reports, articles, and websites) and provided basic information, then 15 experts were selected to complete the questionnaire. Experts are affiliated to the public, private and academic/ educational bodies to reflect different actors' opinions in the results to ensure unbiased and inclusive results. Selected academic experts have research activities in the field of sustainable development and were sufficiently familiar with the concepts of SDGs in theory and practice. Government experts are those in charge of implementing the SDG Agenda in Iran. Experts selected from private companies also have knowledge and experience on sustainable development agenda. Relevant description, including questionnaires, were sent to experts, and group meetings were convened with 15 experts in the winter of 2019 (November 11, 2019). They were provided explanations about ISM and SDGs methods to complete the questionnaire. Subsequently they filled questionnaires in person. The research territory is Iran and its temporal interval is from 2018 to 2020. Thus, the experts, considering the conditions of Iran in these years, proceeded to complete the questionnaire.

The steps of the interpretive structural modeling method [33, 34] that have been performed in the present study are as follows:

\subsection{Structural Self-Interaction Matrix (SSIM)}

A self-interacting structural matrix is a variable-sized matrix in which the first row and column of those variables are listed in order and are formed on the basis of the expert group views. The relationship between issues is analyzed in two ways, both pairs, and experts use the following symbols. The symbol (V) is used when the index (i) is lead to ( $\mathrm{j}$ ). The symbol (A) is used when index (j) leads to (i). The symbol (X) is used if there is a two-way connection between the row (i) and the column (j) and that both indices underlie each other. Finally, the symbol $(\mathrm{O})$ is used to show the absence of a relationship between the two elements.

\subsection{Initial Reachability Matrix}

Initial Reachability Matrix is created by converting the SSIM into a two-value matrix (zero and one). The rules for formulating this matrix are as follows:

In the SSIM if the cell $(i, j)$ is assigned symbol (V), (A), (X) and $(\mathrm{O})$, in the initial reachability matrix, this cell $(i, j)$ entry becomes respectively $1,0,1$ and 0 and the cell $(\mathrm{j}, \mathrm{i})$ entry becomes $0,1,1$ and 0 respectively.

\subsection{Final Reachability Matrix}

After the initial reachability matrix is created, an internal consistency has to be determined in it. For instance, if variable (i) leads to variable (j), and variable (j) leads to variable $(k)$, then, variable (i) must also lead to variable $(\mathrm{k})$, and if this relationship does not hold in the reachability matrix, then the matrix should be modified and the missing relationships must be substituted. Various methods have been proposed to achieve consistency in the matrix. In the present study, the Boolean rule was used to convert the initial reachability to the final reachability matrix, which was performed by MATLAB b2016a software.

\subsection{Level partitions}

To discover the relationship and leveling of the elements, the Reachability Set and the Antecedent Set must be calculated for each variable. The Reachability set entails variables and variables that are affected by it. The Antecedent Set comprises of each variable and variables that affected it. This step is 
undertaken using the reachability matrix. When the Reachability and Antecedent sets are calculated for each variable, the Intersection set in these sets is identified for each variable. As the antecedent and reachability and intersection sets are calculated, the levels of the variables become known. In Table 1, the variable with completely similar reachability and intersection sets has the highest level. After identifying the former variable(s), they are removed from the table, and a table is created by the remaining variables. This process stops when the level of all the variables are assigned.

\subsection{Mapping the diagraph or model}

After the relationships and the variable levels are determined, their diagraph can be mapped. First, the variables are arranged from top to bottom based-on their levels, and a consistent reachability matrix arranged by level and the structural hierarchy is mapped. If the relationships between the variables from (i) to (j) exist, they are shown with arrows.

\subsection{MICMAC analysis}

The MICMAC analysis determines and analyzes variables driving power (D.P) and dependence (D). In MICMAC, variables are categorized into four batches based on their D.P and D:

1) Autonomous variables: that have a poor D.P and D. These variables have poor relations with the system and have nearly no link to the system. 2) Dependent variables: that have a poor D.P, but a high D. 3) Linkage variables that have high D.P and D. These variables are dynamic, since every change in them can affect the system, and the system's feedback can, in turn, change the variables once again. 4) Independent variables (driving variables): that have a high D.P but a low D. We will describe the status of each SDGs in the MICMAC analysis in four clusters of autonomous, dependent, Linkage, and Independent variables in the Findings and Conclusions section.

\section{FINDINGS}

In this study, we first proceed to extract the SSIM using the opinion of experts and on the basis the symbols described in the first step of the research method, the result of which can be seen in Table 4.

Table 4. Structural Self-Interaction Matrix (SSIM)

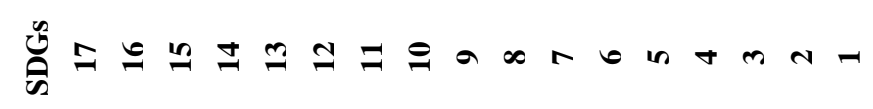

\begin{tabular}{cccccccccccccccccc}
\hline$\rightarrow$ & $\mathrm{A}$ & $\mathrm{O}$ & $\mathrm{O}$ & $\mathrm{O}$ & $\mathrm{O}$ & $\mathrm{O}$ & $\mathrm{O}$ & $\mathrm{O}$ & $\mathrm{O}$ & $\mathrm{A}$ & $\mathrm{O}$ & $\mathrm{O}$ & $\mathrm{O}$ & $\mathrm{O}$ & $\mathrm{A}$ & $\mathrm{A}$ & - \\
\hline $\mathrm{N}$ & $\mathrm{A}$ & $\mathrm{O}$ & $\mathrm{O}$ & $\mathrm{O}$ & $\mathrm{O}$ & $\mathrm{O}$ & $\mathrm{O}$ & $\mathrm{O}$ & $\mathrm{O}$ & $\mathrm{O}$ & $\mathrm{O}$ & $\mathrm{O}$ & $\mathrm{O}$ & $\mathrm{O}$ & $\mathrm{A}$ & - & - \\
\hline$\sim$ & $\mathrm{O}$ & $\mathrm{O}$ & $\mathrm{O}$ & $\mathrm{O}$ & $\mathrm{O}$ & $\mathrm{O}$ & $\mathrm{O}$ & $\mathrm{O}$ & $\mathrm{O}$ & $\mathrm{O}$ & $\mathrm{O}$ & $\mathrm{O}$ & $\mathrm{O}$ & $\mathrm{O}$ & - & - & - \\
\hline+ & $\mathrm{O}$ & $\mathrm{O}$ & $\mathrm{O}$ & $\mathrm{O}$ & $\mathrm{O}$ & $\mathrm{O}$ & $\mathrm{V}$ & $\mathrm{O}$ & $\mathrm{V}$ & $\mathrm{O}$ & $\mathrm{O}$ & $\mathrm{O}$ & $\mathrm{V}$ & - & - & - & - \\
\hline$\sim$ & $\mathrm{O}$ & $\mathrm{O}$ & $\mathrm{O}$ & $\mathrm{O}$ & $\mathrm{O}$ & $\mathrm{O}$ & $\mathrm{O}$ & $\mathrm{O}$ & $\mathrm{O}$ & $\mathrm{O}$ & $\mathrm{O}$ & $\mathrm{O}$ & - & - & - & - & - \\
\hline$\bullet$ & $\mathrm{O}$ & $\mathrm{O}$ & $\mathrm{V}$ & $\mathrm{A}$ & $\mathrm{V}$ & $\mathrm{A}$ & $\mathrm{V}$ & $\mathrm{O}$ & $\mathrm{O}$ & $\mathrm{O}$ & $\mathrm{O}$ & - & - & - & - & - & - \\
\hline$\sim$ & $\mathrm{O}$ & $\mathrm{O}$ & $\mathrm{O}$ & $\mathrm{O}$ & $\mathrm{A}$ & $\mathrm{O}$ & $\mathrm{V}$ & $\mathrm{O}$ & $\mathrm{O}$ & $\mathrm{O}$ & - & - & - & - & - & - & - \\
\hline$\infty$ & $\mathrm{A}$ & $\mathrm{A}$ & $\mathrm{O}$ & $\mathrm{O}$ & $\mathrm{O}$ & $\mathrm{O}$ & $\mathrm{A}$ & $\mathrm{V}$ & $\mathrm{A}$ & - & - & - & - & - & - & - & - \\
\hline$\sigma$ & $\mathrm{V}$ & $\mathrm{O}$ & $\mathrm{O}$ & $\mathrm{O}$ & $\mathrm{O}$ & $\mathrm{O}$ & $\mathrm{V}$ & $\mathrm{O}$ & - & - & - & - & - & - & - & - & - \\
\hline
\end{tabular}

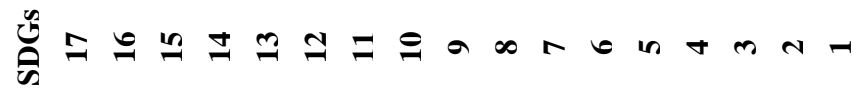

\begin{tabular}{|c|c|c|c|c|c|c|c|c|c|c|c|c|c|c|c|}
\hline$ㅇ ㅡ$ & $\mathrm{O}$ & $\mathrm{O}$ & $\mathrm{O}$ & & U & C & - & - & & & & & - & - & \\
\hline$=0$ & $\mathrm{O}$ & A & A & $\mathrm{O}$ & A & - & - & - & & - & - & - & - & - & - \\
\hline$\simeq \mathrm{O}$ & $\mathrm{O}$ & V & V & $\mathrm{O}$ & - & - & - & - & - & - & - & - & - & - & - \\
\hline$\cong 0$ & $\mathrm{O}$ & V & V & - & - & - & - & - & - & - & - & - & - & - & - \\
\hline \pm 0 & $\mathrm{O}$ & $\mathrm{O}$ & - & - & - & - & - & - & - & - & - & - & - & - & - \\
\hline$\cong 0$ & $\mathrm{O}$ & - & - & - & - & - & - & - & - & - & - & - & - & - & - \\
\hline
\end{tabular}

금

To achieve the initial matrix, we converted the symbols mentioned in Table 3 into zero and one symbols based on what we explained in the second step of the research methodology. Thus, the initial reachability matric was extracted, which can be seen in Table 5 .

Table 5. Reachability matrix

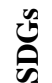
-

\begin{tabular}{cccccccccccccccccc}
\hline$\neg$ & 1 & 0 & 0 & 0 & 0 & 0 & 0 & 0 & 0 & 0 & 0 & 0 & 0 & 0 & 0 & 0 & 0 \\
\hline$\sim$ & 1 & 1 & 0 & 0 & 0 & 0 & 0 & 0 & 0 & 0 & 0 & 0 & 0 & 0 & 0 & 0 & 0 \\
\hline$\sim$ & 1 & 1 & 1 & 0 & 0 & 0 & 0 & 0 & 0 & 0 & 0 & 0 & 0 & 0 & 0 & 0 & 0 \\
\hline$\neg$ & 0 & 0 & 0 & 1 & 1 & 0 & 0 & 0 & 1 & 0 & 1 & 0 & 0 & 0 & 0 & 0 & 0 \\
\hline$\curvearrowleft$ & 0 & 0 & 0 & 0 & 1 & 0 & 0 & 0 & 0 & 0 & 0 & 0 & 0 & 0 & 0 & 0 & 0 \\
\hline$\bullet$ & 0 & 0 & 0 & 0 & 0 & 1 & 0 & 0 & 0 & 0 & 1 & 0 & 1 & 0 & 1 & 0 & 0 \\
\hline$\sim$ & 0 & 0 & 0 & 0 & 0 & 0 & 1 & 0 & 0 & 0 & 1 & 0 & 0 & 0 & 0 & 0 & 0 \\
\hline$\infty$ & 1 & 0 & 0 & 0 & 0 & 0 & 0 & 1 & 0 & 1 & 0 & 0 & 0 & 0 & 0 & 0 & 0 \\
\hline$\curvearrowleft$ & 0 & 0 & 0 & 0 & 0 & 0 & 0 & 1 & 1 & 0 & 1 & 0 & 0 & 0 & 0 & 0 & 1 \\
\hline
\end{tabular}
$\varrho \begin{array}{lllllllllllllllll}0 & 0 & 0 & 0 & 0 & 0 & 0 & 0 & 0 & 1 & 0 & 0 & 0 & 0 & 0 & 0 & 0\end{array}$

$=\begin{array}{lllllllllllllllll}0 & 0 & 0 & 0 & 0 & 0 & 0 & 1 & 0 & 0 & 1 & 0 & 0 & 0 & 0 & 0 & 0\end{array}$

エ $0 \begin{array}{lllllllllllllllllll}0 & 0 & 0 & 0 & 0 & 1 & 0 & 0 & 0 & 0 & 1 & 1 & 0 & 1 & 1 & 0 & 0\end{array}$

ฯ 0 \begin{tabular}{lllllllllllllllllll}
\hline & 0 & 0 & 0 & 0 & 0 & 1 & 0 & 0 & 0 & 0 & 0 & 1 & 1 & 1 & 0 & 0
\end{tabular}

\begin{tabular}{lllllllllllllllllll}
\hline$\unlhd$ & 0 & 0 & 0 & 0 & 1 & 0 & 0 & 0 & 0 & 1 & 0 & 0 & 1 & 0 & 0 & 0 \\
\hline$\curvearrowleft$ & 0 & 0 & 0 & 0 & 0 & 0 & 0 & 0 & 0 & 0 & 1 & 0 & 0 & 0 & 1 & 0 & 0 \\
\hline
\end{tabular}

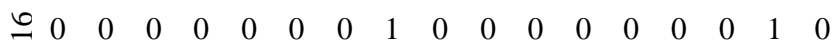

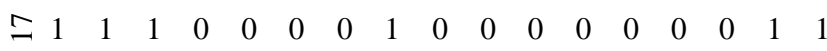

After the initial reachability is obtained, we must establish internal consistency in it according to the third step of the research method. For this purpose, we used the Boolean rule to convert the initial reachability to final reachability, which was performed by MATLAB b2016a software. In Table 6 , the numbers that bear the $(*)$ sign indicate that the initial 
reachability was zero and after establishing the internal consistency, they took the number one. In this matrix, we also determined D.P and D) of each variable against other variables. The D.P of each variable is calculated from the summation of variables affected by it and the variable itself. The $\mathrm{D}$ of a variable is calculated from the summation of the variables that affected it and the variable itself. The result of the final matrix table indicates which variable has the most and least impact. This table will be our basis for MICMAC analysis.

Table 6. Final reachability matrix

\begin{tabular}{|c|c|c|c|c|c|c|c|c|c|c|c|c|c|c|c|c|c|c|}
\hline 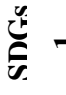 & - & & & $\nabla$ & & $v$ & & $\propto$ & $\sigma$ & $\subseteq$ & & & & & $\underline{1}$ & $\underline{\varepsilon}$ & & $\hat{\epsilon}$ \\
\hline-1 & 0 & 0 & ) & 0 & 0 & 0 & 0 & 0 & 0 & 0 & 0 & 0 & 0 & 0 & 0 & 0 & 0 & \\
\hline$\curvearrowright 1$ & 1 & 0 & ) & 0 & 0 & 0 & 0 & 0 & 0 & 0 & 0 & 0 & 0 & 0 & 0 & 0 & 0 & \\
\hline$\curvearrowright 1$ & 1 & 1 & 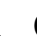 & 0 & 0 & 0 & 0 & 0 & 0 & 0 & 0 & 0 & 0 & 0 & 0 & 0 & 0 & r \\
\hline$\diamond{ }_{*}^{1}$ & & $\begin{array}{l}1 \\
*\end{array}$ & & 1 & 1 & 0 & 0 & $\begin{array}{l}1 \\
*\end{array}$ & 1 & $\begin{array}{l}1 \\
*\end{array}$ & 1 & 0 & 0 & 0 & 0 & $\begin{array}{l}1 \\
*\end{array}$ & $\begin{array}{l}1 \\
*\end{array}$ & $=$ \\
\hline ir 0 & 0 & 0 & ) & 0 & 1 & 0 & 0 & 0 & 0 & 0 & 0 & 0 & 0 & 0 & 0 & 0 & 0 & - \\
\hline$\underbrace{1}_{*}$ & 0 & 0 & & 0 & 0 & 1 & $\begin{array}{l}1 \\
*\end{array}$ & $\begin{array}{l}1 \\
*\end{array}$ & 0 & $\begin{array}{l}1 \\
*\end{array}$ & 1 & 0 & 1 & $\begin{array}{l}1 \\
*\end{array}$ & 1 & 0 & 0 & $\sigma$ \\
\hline & 0 & 0 & & 0 & 0 & 0 & 1 & $\begin{array}{l}1 \\
*\end{array}$ & 0 & $\begin{array}{l}1 \\
*\end{array}$ & 1 & 0 & 0 & 0 & 0 & 0 & 0 & r \\
\hline$\propto 1$ & 0 & 0 & & 0 & 0 & 0 & 0 & 1 & 0 & 1 & 0 & 0 & 0 & 0 & 0 & 0 & 0 & r \\
\hline & & $\begin{array}{l}1 \\
*\end{array}$ & & 0 & 0 & 0 & 0 & 1 & 1 & $\begin{array}{l}1 \\
*\end{array}$ & 1 & 0 & 0 & 0 & 0 & $\begin{array}{l}1 \\
*\end{array}$ & 1 & $\sigma$ \\
\hline-0 & 0 & 0 & & 0 & 0 & 0 & 0 & 0 & 0 & 1 & 0 & 0 & 0 & 0 & 0 & 0 & 0 & - \\
\hline$=\begin{array}{l}1 \\
*\end{array}$ & 0 & 0 & & 0 & 0 & 0 & 0 & 1 & 0 & $\begin{array}{l}1 \\
*\end{array}$ & 1 & 0 & 0 & 0 & 0 & 0 & 0 & $\nabla$ \\
\hline$\simeq \quad 1$ & 0 & 0 & & 0 & 0 & 1 & $\begin{array}{l}1 \\
*\end{array}$ & $\begin{array}{l}1 \\
*\end{array}$ & 0 & $\begin{array}{l}1 \\
*\end{array}$ & 1 & 1 & $\begin{array}{l}1 \\
*\end{array}$ & 1 & 1 & 0 & 0 & $\subseteq$ \\
\hline$\simeq{ }_{*}^{1}$ & 0 & 0 & & 0 & 0 & $\begin{array}{l}1 \\
*\end{array}$ & 1 & $\begin{array}{l}1 \\
*\end{array}$ & 0 & $\begin{array}{l}1 \\
*\end{array}$ & $\begin{array}{l}1 \\
*\end{array}$ & 0 & 1 & 1 & 1 & 0 & 0 & 0 \\
\hline \pm 1 & 0 & 0 & & 0 & 0 & 1 & $\begin{array}{l}1 \\
*\end{array}$ & $\begin{array}{l}1 \\
*\end{array}$ & 0 & $\begin{array}{l}1 \\
*\end{array}$ & 1 & 0 & $\begin{array}{l}1 \\
*\end{array}$ & 1 & $\begin{array}{l}1 \\
*\end{array}$ & 0 & 0 & $\sigma$ \\
\hline$\underline{r}_{*}^{1}$ & 0 & 0 & & 0 & 0 & 0 & 0 & $\begin{array}{l}1 \\
*\end{array}$ & 0 & $\begin{array}{l}1 \\
*\end{array}$ & 1 & 0 & 0 & 0 & 1 & 0 & 0 & $r$ \\
\hline$\underbrace{}_{*} 1$ & 0 & 0 & & 0 & 0 & 0 & 0 & 1 & 0 & $\begin{array}{l}1 \\
*\end{array}$ & 0 & 0 & 0 & 0 & 0 & 1 & 0 & $\nabla$ \\
\hline$\simeq 1$ & 1 & 1 & & 0 & 0 & 0 & 0 & 1 & 0 & $\begin{array}{l}1 \\
*\end{array}$ & 0 & 0 & 0 & 0 & 0 & 1 & 1 & $r$ \\
\hline
\end{tabular}

After the final reachability matrix is obtained, we proceed the level of each variable based on the fourth step of the research method is calculated. A variable is placed in level one which has perfectly similar reachability and intersection sets. This iteration continues until all the levels are filled which is shown in Table 7.

After determining the levels of each of the variables, we mapped the structural interpretive model of SDGs in Iran considering the final reachability matrix, which is shown in Figure 1.

The model we obtained consists of 6 levels. Variables at higher levels of the hierarchy are less influential, for instance, variables such as SDGs 5 and 10. On the other hand, variables which are at lower levels of the hierarchy are more influential, for instance, variables such as SDGs 12 and 4.
After mapping the interpretive structural model of SDGs in Iran, we proceed to analyze MICMAC, in which the variables are categorised into 4 groups according to the sixth step of the research method. Table 6 presents the D.P and D of variables. For this analysis, a table should be designed with the number of variables (17 variables) in the row and column. Each variable has a specific driving power and dependence in the row axis (dependence) and column axis (driving power). In other words, each factor in Table 6 has two numbers, dependence in the table row and the driving power in the table column are specified and the intersection point of the row and column determines the position of the factor in the MICMAC analysis.

Table 7. Level partitions of SDGs

\begin{tabular}{|c|c|c|c|c|}
\hline की & $\begin{array}{c}\text { Reachability } \\
\text { set }\end{array}$ & Antecedent set & $\begin{array}{c}\text { Interaction } \\
\text { set }\end{array}$ & d \\
\hline- & 1 & $\begin{array}{c}1,2,3,4,6,7,8,9,11,12,1 \\
3,14,15,16,17 \\
\end{array}$ & 1 & I \\
\hline$n$ & 5 & 4,5 & 5 & I \\
\hline 으 & 10 & $\begin{array}{c}4,6,7,8,9,10,11,12,13 \\
14,15,16,17 \\
\end{array}$ & 10 & I \\
\hline$N$ & 2 & $2,3,4,9,7$ & 2 & II \\
\hline$\infty$ & 8 & $\begin{array}{c}4,6,7,8,9,11,12,13,14 \\
15,16,17\end{array}$ & 8 & II \\
\hline$m$ & 3 & $3,4,9,7$ & 3 & III \\
\hline$=$ & 11 & $4,6,7,9,11,12,13,14,15$ & 11 & III \\
\hline$\underline{0}$ & 16 & $4,9,16,17$ & 16 & III \\
\hline$r$ & 7 & $6,7,12,13,14$ & 7 & IV \\
\hline$\because$ & 15 & $6,12,13,14,15$ & 15 & IV \\
\hline$\Xi$ & 17 & 9,17 & 17 & IV \\
\hline 6 & $6,13,14$ & $6,12,13,14$ & $6,13,14$ & $\mathrm{~V}$ \\
\hline$a$ & 9 & 4,9 & 9 & $\mathrm{~V}$ \\
\hline$\cong$ & $6,13,14$ & $6,12,13,14$ & $6,13,14$ & $\mathrm{~V}$ \\
\hline$\Xi$ & $6,13,14$ & $6,12,13,14$ & $6,13,14$ & $\mathrm{~V}$ \\
\hline$\nabla$ & 4 & 4 & 4 & VI \\
\hline$\simeq$ & 12 & 12 & 12 & VI \\
\hline
\end{tabular}

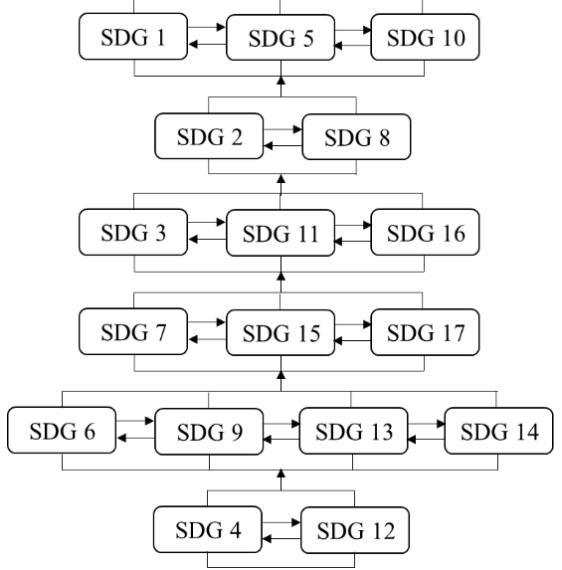

Figure 1. Hierarchy of SDGs 
The first group includes autonomous variables that have poor D.P and D. SDGs2, 3, 5, 7, 15, 16, 17, and 17 are placed in this cluster, as shown in the diagraph of D.P and D. These variables are somewhat different from other variables and have poor relations with the system. The second group is dependent variables that have poor D.P but high D and effectiveness. In other words, many variables are effective in creating this variable, and this variable itself can be less likely to form the basis for the formation of other variables. SDGs 1, 8,10 , and 11 are in this group. The third group includes linkage variables that have high D.P and D that none of the variables are placed in this cluster; any change in this variable affects other variables. The fourth group includes independent variables. These variables have high D.P and low D; SDGs 4, $6,9,12,13$, and 14 are placed in this cluster.

\section{DISCUSSION}

In this study, SDGs are presented in the form of an interpretive structural model because all of these goals are interrelated. Therefore, before planning to achieve SDGs, policymakers need to be aware of the level of interaction among goals and how they affect each other. The present study aims to provide insight into the interaction and how SDGs affect each other in the context of Iran and the way to achieve them. Understanding the interactions between goals and knowing the prerequisites is very important before trying to achieve a specific goal. Some goals cannot be achieved before knowing the goal of the prerequisites. For example, if we want to achieve SDG 1 which means no poverty, we cannot achieve this goal without achieving SDG 8, or decent work and economic growth, and SDG 9 or industry, innovation, and infrastructure, which is also mentioned in the research of Kumar et al. [4] and Zaini and Akhtar [15]. Similarly, we will not be able to achieve SDG 11, i.e. sustainable cities and communities, if we have not achieved SDG 6, meaning clean water and sanitation, and SDG 13, which means climate action. According to our research, SDG 4 meaning quality education and SDG 12 meaning responsible consumption and production are the most essential goals. In the studies of Kumar et al. [4] and Zaini and Akhtar [15], SDG 4, i.e. quality education, has been identified as the most essential goal, still, SDG 12, i.e. responsible consumption and production in their research, has not been identified as an essential goal, although Türkeli [5] also mentions it as one of the important goals.

MICMAC analysis also showed that SDGs 4, 6, 9, 12, 13, and 14 are independent variables with high D.P and low D, which also in the study of Kumar et al. [4] SDGs 13 and 14 are mentioned as independent variables. Also in Zaini and Akhtar's [15] study, SDG 12 is in this cluster, and in all three studies, SDG 4 has been identified as an independent variable. SDGs 6 and 9 are independent variables in our study, which do not rank high in the studies of Kumar et al. [4] and Zaini and Akhtar [15]. This means that, along with quality education and responsible consumption and production and, policymakers must pay attention to clean water and sanitation, industry, innovation and infrastructure, climate action and sustainable life below water in their planning. Also, in the present study, like the research of Kumar et al. [4], none of the goals were identified as the linkage variable, which is contrary to the research of Zaini and Akhtar [15]. In the present study, SDGs $2,3,5,7,15,16$, and 17 arbitration in the cluster of autonomous variables, which have poor D.P and D, which in the studies by Kumar et al, SDGs 5, 9, 10, 12 and in the studies by Zaini and Akhtar [15], SDGs 7 and 13 are in this cluster. These variables are somewhat different from other variables and have poor relations with the system. Finally, SDGs 1, 8, 10 , and eleven have been identified as dependent variables in this study. These variables have poor D.P but high D and effectiveness. The study by Kumar et al. [4] also named SDGs $2,3,8,11,16$, and 17 as dependent variables. Also in Zaini and Akhtar's [15] study, SDG 2, 3, 6, and 15 are in this cluster, and in all three studies, SDG 1 has been identified as a dependent variable.

Table 8. The main custodians of SDGs in Iran (National level)

\begin{tabular}{cc}
\hline SDGs & Custodian \\
\hline 1 & Ministry of Cooperatives, Labour, and Social Welfare \\
\hline 2 & Ministry of Agriculture \\
\hline 3 & Ministry of Health and Medical Education \\
\hline 4 & Ministry of Education \\
\hline 5 & Vice Presidency for Women and Family Affairs \\
\hline 6 & Ministry of Energy \\
\hline 7 & Ministry of Energy \\
\hline 8 & Ministry of Economic Affairs and Finance \\
\hline 9 & Ministry of Industry, Mine and Trade \\
\hline 10 & Ministry of Economic Affairs and Finance \\
\hline 11 & Ministry of Roads and Urban Development \\
\hline 12 & Planning and Budget Organization \\
\hline 13 & Department of Environment \\
\hline 14 & Department of Environment \\
\hline 15 & Department of Environment \\
\hline 16 & Ministry of Interior \\
\hline 17 & Planning and Budget Organization \\
\hline
\end{tabular}

Given the importance of planning and policy-making at the national level for achieving Sustainable Development Goals (SDGs) in the present study, in addition to presenting all SDGs in a form of an interpretive structural model so that policymakers are aware of the level of interaction among goals and how they affect each other, the supervisors overseeing each of the objectives have been identified, as outlined in Table 8. Trustees can play an important role in building understanding, cooperation, and coordination with other stakeholders to achieve these goals.

\section{CONCLUSIONS}

In the present study, in addition to stating the importance of each of the SDGs, the relationships among each of them were systematically expressed in the form of a hierarchical structure. This helps policy-makers to acquire a clear comprehension of the relationships among SDGs and to understand the role of each SDGs in achieving other SDGs. Also, D.P and D of each of the SDGs was presented in the form of MICMAC analysis. SDGs, which are the base of ISM, is the most essential goals and prerequisites, and without achieving these goals, which are in SDGs 4 and 12 in the present study, other goals cannot be achieved. Therefore, better results can be achieved by improving these prerequisites and essential goals. In a nutshell, the present study could provide the following insights for policymakers:

- The hierarchical model developed using the ISM method has been used to investigate the interrelationships among SDGs in Iran. This will help decision-makers and 
policymakers identify a hierarchy of measures to achieve SDGs in Iran.

- The interrelationships among SDGs are presented in a hierarchical structure that can help decision-makers and policymakers to visualize the priority level of each SDG as well as allocate appropriate resources and time.

- SDGs 1, 5, and 10 appear at the top of the hierarchical model, indicating that to improve these goals, they need to improve on other variables below these goals. Also, SDGs 1 and 10 are in the second cluster (Figure 2), which shows that many variables are effective in achieving these SDGs, and this variable itself can be less likely to form the basis for the formation of other variables.

- Lack of variables in the $3^{\text {rd }}$ cluster (Figure 2), linkage variables, indicates that none of the SDGs have simultaneously high driving power and dependency. Any change in these variables affects other variables.

- Decision-makers and policymakers should pay special attention to SDGs 4 and 12. These goals are the most essential goals and prerequisites, and without achieving these goals, other goals cannot be achieved. These goals are in the fourth cluster i.e. the independent variables and have high driving power.

- Also, SDGs 9, 6, 13, and 14, although are located at the middle levels of the hierarchy, are highly influential and need to be considered by decision-makers and policymakers.

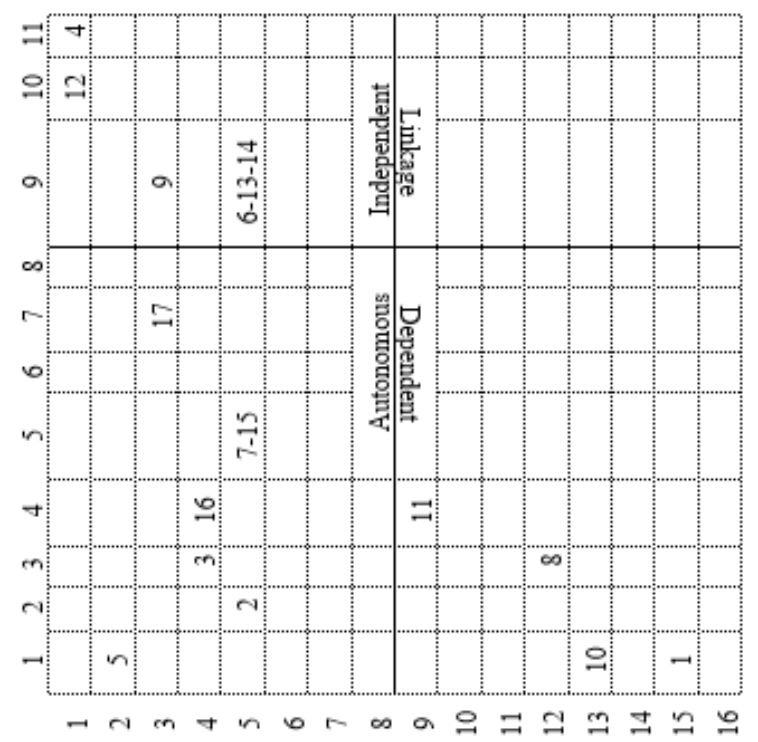

Figure 2. MICMAC analysis of SDGs

The study sought to provide decision-makers and policymakers with tools to achieve SDGs in Iran. However, decision-makers and policymakers must simultaneously consider several other constraints, such as financial issues, social awareness, and political support. In future studies, we intend to use another modeling and ranking method to analyze the challenges and barriers to clean energy development (SDG7) in Iran and provide an insight that can help decisionmakers and policymakers plan more accurately.

\section{REFERENCES}

[1] OECD. (2016). Better Policies for 2030: An OECD action plan on the sustainable development goals. Paris:
Organisation for Economic Co-operation and Development.

https://www.oecd.org/dac/Better\%20Policies $\% 20$ for $\% 2$ 02030.pdf

[2] Bobylev, S.N., Solovyeva, S.V. (2017). Sustainable development goals for the future of Russia. Studies on Russian Economic Development, 28(3): 259-265. http://dx.doi.org/10.1134/S1075700717030054

[3] Moyer, J., Hedden, S. (2020). Are we on the right path to achieve the sustainable development goals? World Development, 127: http://dx.doi.org/10.1016/j.worlddev.2019.104749

[4] Kumar, P., Ahmed, F., Singh, R., Sinha, P. (2017). Determination of hierarchical relationships among sustainable development goals using interpretive structural modeling. Environment Development and Sustainability, 20: 2119-2137. http://dx.doi.org/10.1007/s10668-017-9981-1

[5] Türkeli, S. (2020). Complexity and the sustainable development goals: A computational intelligence approach to support policy mix designs. Journal of Sustainable Research, 2(1): e200006. https://doi.org/10.20900/jsr20200006

[6] FAO. (2017). FAO and the SDGs Indicators: Measuring up to the 2030 Agenda for Sustainable Development, Rome: Food and Agriculture Organization of the United Nations. http://www.fao.org/3/a-i6919e.pdf.

[7] UN. (2018). The 2030 Agenda and the Sustainable Development Goals: An opportunity for Latin America and the Caribbean. Santiago: United Nations.

[8] Kulshreshtha, S.N., Musaba, E. (2016). Sustainability considerations in biofuel development in Saskatchewan, Canada. International Journal of Sustainable Development and Planning, 11(2): 128-137. https://doi.org/10.2495/SDP-V11-N2-128-137

[9] Sachs, J., Schmidt-Traub, G., Kroll, C., Lafortune, G., Fuller, G., Woelm, F. (2020). The Sustainable Development Goals and COVID-19. Sustainable Development Report 2020. Cambridge: Cambridge University Press.

[10] Ministry of Energy. (2020). Annual statistical report of water and electricity industry. Tehran: Ministry of Energy. https://isn.moe.gov.ir/?lang=en-us.

[11] Schwab, K. (2019). The Global Competitiveness Report 2019. Geneva: World Economic Fourm. http://www3.weforum.org/docs/WEF_TheGlobalComp etitivenessReport2019.pdf.

[12] Keshavarz Mohammadi, N., Sayyari, A., Farshad, A., Jahanmehr, N., Siddiqi, S., Taghizadeh, R., Dye, C. (2019). From MDGs to SDGs: New impetus to advance health in Iran. Journal of Health Scope, 8(3): e86420. https://doi.org/10.5812/jhealthscope. 86420

[13] FAO. (2020). Working with countries of Asia and the Pacific to achieve the 2030 Agenda. Bangkok: Food and Agriculture Organization of the United Nations. http://www.fao.org/3/ca7578en/CA7578EN.pdf.

[14] Widiati, W., Mulyadi, A., Syahza, A., Mubarak. (2020). Analysis of plantation management achievement based on sustainable development. International Journal of Sustainable Development and Planning, 15(4): 575-584. https://doi.org/10.18280/ijsdp.150418

[15] Zaini, S., Akhtar, A. (2019). Modelling the sustainable development goals for India - an interpretive structural modelling approach. World Review of Science, 
Technology and Sustainable Development, 15(1): 46-65. http://dx.doi.org/10.1504/WRSTSD.2019.098677

[16] Mensah, J. (2019). Sustainable development: Meaning, history, principles, pillars, and implications for human action: Literature review. Cogent Social Sciences, 5(1): 1653531.

http://dx.doi.org/10.1080/23311886.2019.1653531

[17] Klarin, T. (2018). The concept of sustainable development: from its beginning to the contemporary issues. Zagreb International Review of Economics \& Business, 21(1): 67-94. http://dx.doi.org/10.2478/zireb2018-0005

[18] Shi, L., Han, L., Yang, F., Gao, L. (2019). The evolution of sustainable development theory: Types, goals, and research prospects. Sustainability, 11(24): 7158. http://dx.doi.org/10.3390/su11247158

[19] Hwang, S., Kim, J. (2017). UN and SDGs: A Handbook for Youth, Bangkok. United Nations Economic and Social Commission for Asia and the Pacific. https://www.unescap.org/sites/default/d8files/knowledg e-

products/UN\%20and\%20SDGs_A $\% 20$ Handbook $\% 20$ fo r\%20Youth.pdf.

[20] WCED. (1987). Our Common Future. Oxford: Oxford University Press.

[21] Grainger-Brown, J., Malekpour, S. (2019). Implementing the sustainable development goals: a review of strategic tools and frameworks available to organisations. Sustainability, 11(5): 1381. http://dx.doi.org/10.3390/su11051381

[22] Pirlone, F., Spadaro, I. (2017). Sustainable tourism action plan in the Mediterranean coastal areas. International Journal of Sustainable Development and Planning, 12(6): 995-1005. https://doi.org/10.2495/SDPV12-N6-995-1005

[23] Dalampira, E., Nastis, S. (2019). Mapping sustainable development goals: A network analysis framework. Sustainable Development, 28(1): 46-55. http://dx.doi.org/10.1002/sd.1964

[24] Pongiglione, F. (2015). The need for a priority structure for the sustainable development goals. Journal of Global Ethics, 11(1): 37-42. http://dx.doi.org/10.1080/17449626.2014.1001912

[25] Singh, G. (2020). Determining a path to a destination: pairing strategic frameworks with the sustainable development goals to promote research and policy.
Evolutionary and Institutional Economics Review, 17: 521-539. http://dx.doi.org/10.1007/s40844-020-00162-5

[26] Allen, C., Metternicht, G., Wiedmann, T. (2019). Prioritising SDG targets: Assessing baselines, gaps and interlinkages. Sustainability Science, 14: 421-438. http://dx.doi.org/10.1007/s11625-018-0596-8

[27] Weitz, N., Carlse, H., Nilsson, M., Skånberg, K. (2018). Towards systemic and contextual priority setting for implementing the 2030 Agenda. Sustainability Science, 13: 531-548. http://dx.doi.org/10.1007/s11625-0170470-0

[28] Ma, G., Jia, J.Y., Ding, J.Y., Shang, S.S., Jiang, S. (2019). Interpretive structural model based factor analysis of BIM adoption in Chinese construction organizations. Sustainability, 11(7): http://dx.doi.org/10.3390/su11071982

[29] Singh, R., Debnath, R. (2012). Modeling sustainable development: India's strategy for the future. World Journal of Science, Technology and Sustainable Development, $9(2)$ : 120-135. http://dx.doi.org/10.1108/20425941211244270

[30] Behl, A., Pal, A. (2019). Sustainability of environmentally sound technologies using interpretive structural modelling. International Journal of Innovation and Sustainable Development, 13(1): 1-19. http://dx.doi.org/10.1504/IJISD.2019.096702

[31] Attri, R., Dev, N., Sharma, V. (2013). Interpretive structural modelling (ISM) approach: An overview. Research Journal of Management Sciences, 2(2): 3-8.

[32] Gholami, H., Bachok, M.F., Saman, M.Z.M., Streimikiene, D., Sharif, S., Zakuan, N. (2020). An ISM Approach for the Barrier Analysis in Implementing Green Campus Operations: Towards Higher Education Sustainability. $\quad$ Sustainability, $12(1): \quad 363$. http://dx.doi.org/10.3390/su12010363

[33] Ahmad, M., Tang, X.W., Qiu, J.N., Ahmad, F. (2019). Interpretive structural modeling and MICMAC analysis for identifying and benchmarking significant factors of seismic soil liquefaction. Applied Science, 9(2): 233. http://dx.doi.org/10.3390/app9020233

[34] Biswal, J.N., Muduli, K., Satapathy, S. (2018). Interpretive structural modeling-based framework for analysis of sustainable supply chain management enablers: Indian thermal power plant perspective. Journal of Operations and Strategic Planning, 1(1): 34-56. http://dx.doi.org/10.1177/2516600X18774169 